\title{
VI. The rôle of atomic heat in the periodic series of the elements
}

\section{T. Blanshard M.A.}

To cite this article: C. T. Blanshard M.A. (1895) VI. The rôle of atomic heat in the periodic series of the elements, Philosophical Magazine Series 5, 39:236, 106-115, DOI: $10.1080 / 14786449508620685$

To link to this article: http://dx.doi.org/10.1080/14786449508620685

曲 Published online: 08 May 2009.

Submit your article to this journal $[\pi$

Џ Article views: 2

Q View related articles $₫$ 
gas will not emit its definite radiations however high the temperature to which it is raised, unless there is chemical decomposition of the molecules going on. If that be so, the æther does not act as an equalizer of the kinetic energy between the different modes of vibration of the molecules, and the ordinary theory of gases need make no reference to the æather.

If I have understood aright, a similar view has been expressed as at any rate a possible explanation of the difficulty as to the application of Maxwell's distribution theorem in the theory of gases, by Prof. Boltzmann himself. The law of distribution of energy is perhaps unassailable for the case of molecules like small spheres, with three degrees of freedom, all translational. By including the rotational modes of freedom, which may be none at all for a monad gas, only two for a diad, and three for other types, and these possibly not complete, a sufficient number of freedoms is obtained to cover the known range of values of the ratio of the specific heats. The introduction of any vibrational types would make too many ; so on this ground also it is not likely that such types can enter into those among which the thermal energy is divided.-December 4.]

VI. The Rôle of Atomic Heat in the Periodic Series of the Elements. By C. T. BlansaARD, M.A.*

BY a study of the latest, or most accurate data of atomic 1 heats and melting-points I have been enabled to arrive at definite relationships between them, which I will endeavour to set forth. In Grundzüge der theoretiscken Chemie, Leipzig, 1893, p. 106, Lothar Meyer says :- "The periods of fusibility do not coincide with those of other physical characters, are also less regular than these, but are in close relationship to the atomic volume." With regard to Dulong and Petit's law, W. Ostwald says ("Outlines of General Chemistry,' English translation, p. 177) :-“We can only note empirically that the law holds good for substances with atomic weights higher than thirty."

A survey of the accompanying curve of atomic heats, made to correspond with Lothar Meyer's curve of atomic volumes, will, notwithstanding several blanks and sereral doubtful values, demonstrate the two following laws of atomic heat:-

1. The atomic heat decreases in any series from the monad to the tetrad element, and then increases till a maximum is reached with the lieptad element.

* Ccmmunicated by the Author. 
in the Periodic Series of the Elements.

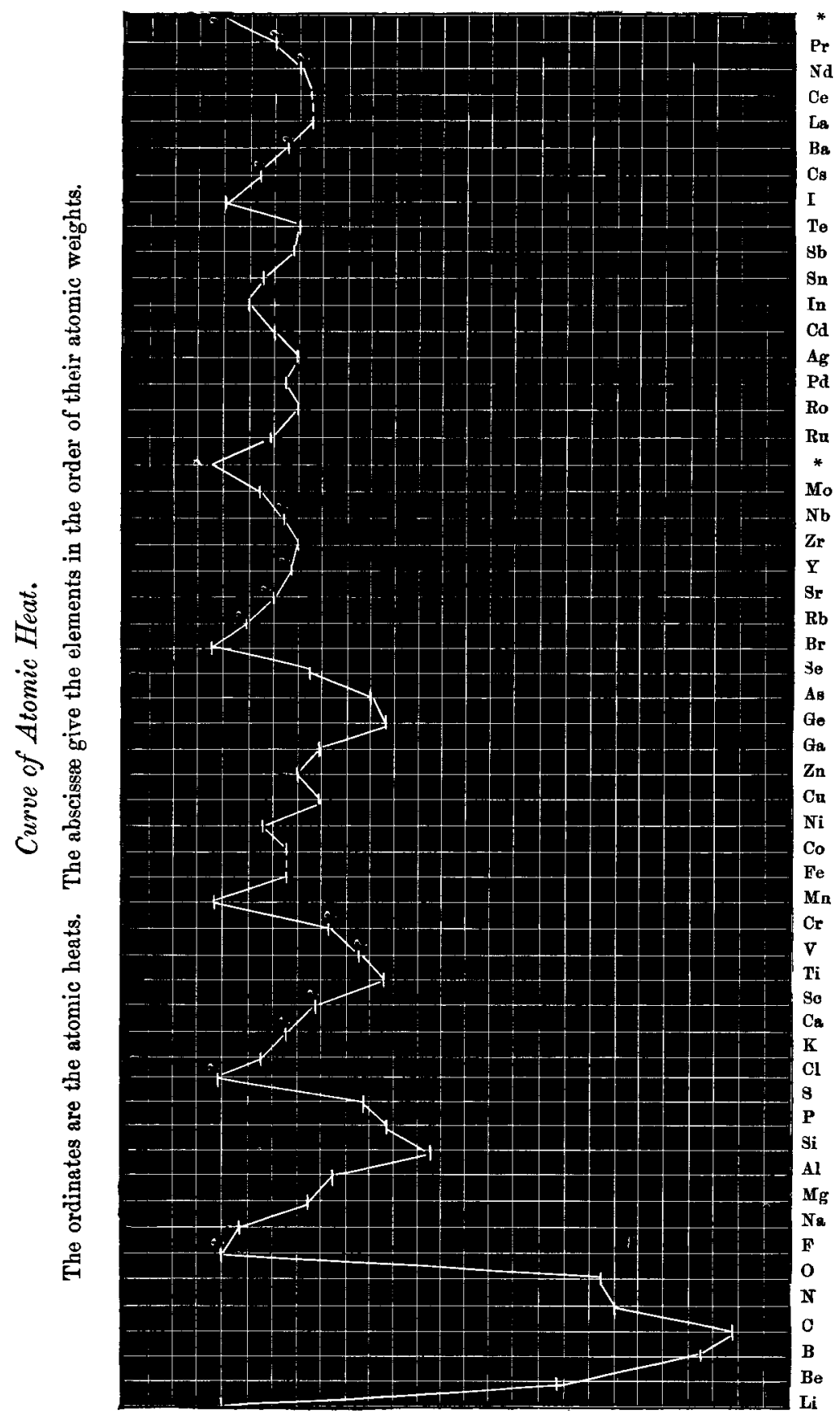

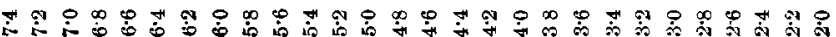


2. The variation is greatest with elements of low atomic weights, becoming less and less as the atomic weight increases.

I hope in the next place to show in a tabular form that the melting-points of the elements are intimately connected with their atomic heats, and that four general laws govern this connexion. Were sufficient data to hand with regard to latent heat of fusion \&c., there is no doubt that many similar relationships would be established. There is evidently plenty of work before physical chemists in this direction. In the arrangement of the groups of elements I follow a plan used by Lothar Meyer, of using Roman numerals combined with lettering. Thus the $\mathrm{Li}$ group is $\mathrm{I}$., the $\mathrm{Cu}$ is I.a.; Group II. is Ca \&c.; II. $a$ Be \&c.; II. $b$ Fe, Ru, Os. In placing the iron elements here, and not in a separate group, I am following W. Preyer, Das genetische System der chemischen Elemente, Berlin, 1893. The groups are entirely arranged by their atomic heats, but will be found to be practically identical with Lothar Meyer's classification. The melting-points taken are the most correct up to date, from (1) the late T. Carnelley's ' Physico-Chemical Constants,' 1.887 ; (2) H. Landolt and R. Börnstein, Phys.Chemische Tabellen, Berlin, 1894 ; (3) The Chemical Society's Journal. Several determinations are very rough, others are altogether wanting. The specific heats, which are much more complete, are from the last two sources and ' Watts' Dictionary of Chemistry.' They are all taken at as near as possible the constant $t^{\circ}, 15^{\circ}$. The atomic weights are from Landolt and Börnstein and the Chemical Society's Journal. From these and the specific heats I have calculated the atomic heats with much greater accuracy than has hitherto been thought necessary. Blanks denote that no reliable data are to hand. A query denotes that the observation has been made, but not accurately.

\begin{tabular}{|c|c|c|c|}
\hline Group. & Element. & Melting-Point. & Atomic Heat. \\
\hline \multirow[t]{5}{*}{ I. .......... } & Lithium. & $180^{\circ}$ & 6.608 \\
\hline & Sodium. & $95 \cdot 6$ & $6 \cdot 526$ \\
\hline & Potassium. & $62 \cdot 5$ & $6 \cdot 303$ \\
\hline & Rubidiuw. & $38 \cdot 5$ & $\ldots \ldots$ \\
\hline & Crsium. & $\begin{array}{r}26 \cdot 5 \\
1054\end{array}$ & $\ldots \ldots 70$ \\
\hline \multirow{2}{*}{ I. $a \ldots \ldots$} & $\begin{array}{l}\text { Copper. } \\
\text { Silver. }\end{array}$ & $\begin{array}{l}1040 \\
1040\end{array}$ & 5.936 \\
\hline & Goid. & 1035 & $6 \cdot 383$ \\
\hline \multirow[t]{2}{*}{ II. } & *Calcium. & $\cdots$ & $7 \cdot 216$ \\
\hline & $\begin{array}{l}\text { Strontium. } \\
\text { Barium. }\end{array}$ & $1100 ?$ & \\
\hline
\end{tabular}

* Bunsen's value for $\mathrm{Ca}$ seems too high; the atornio heat of this eleinent will probably prove to be less than that of $K$. 
Table (continued).

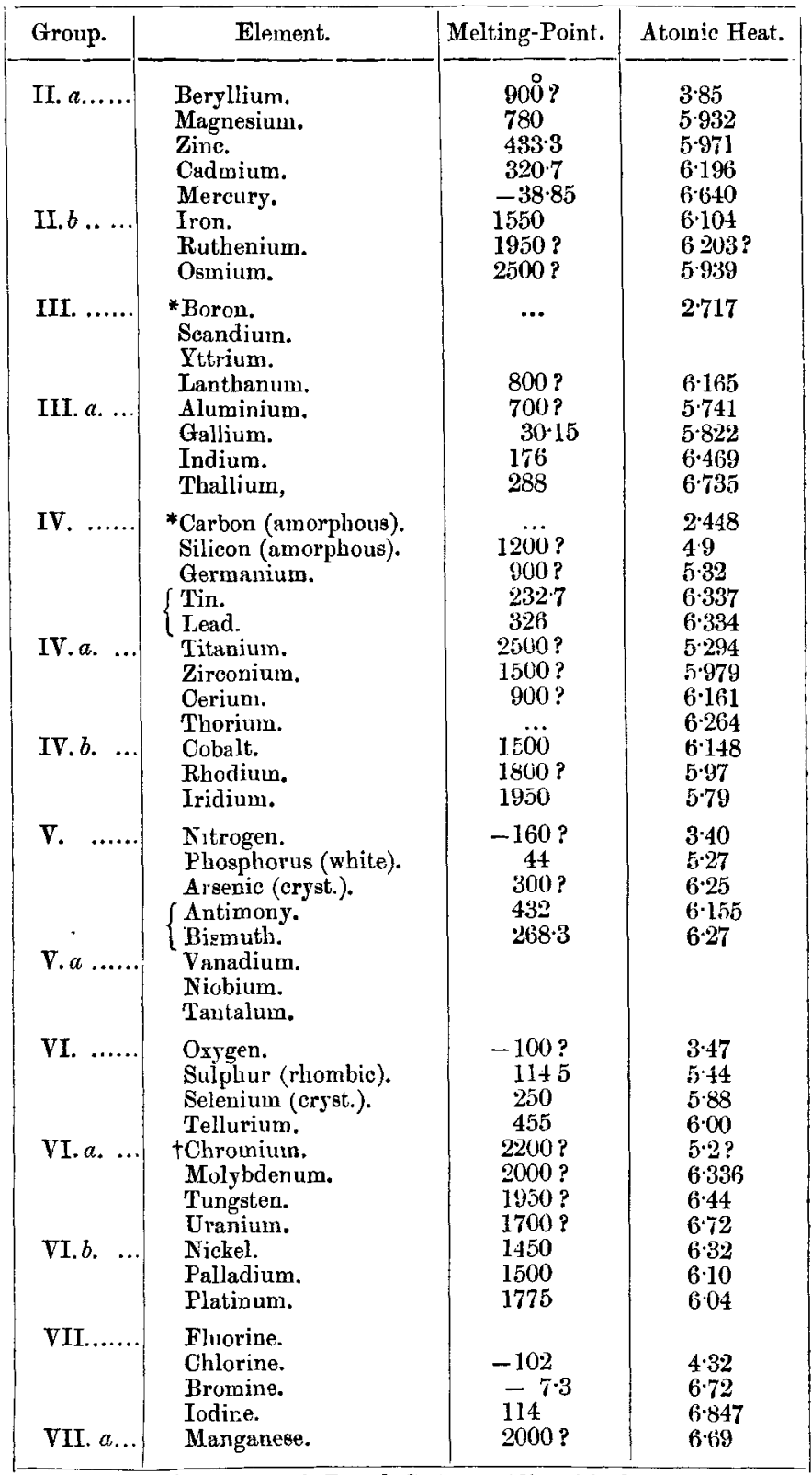

* The specific heats of both $\mathrm{B}$ and $\mathrm{C}$ rise rapidly with the temperature.

$+W$. Preyer's value for $\mathrm{Cr}$ is 62 , which is entirely without foundation though it will probably prove to be nearly correct. 
Authorities.

\begin{tabular}{|c|c|c|c|}
\hline $\begin{array}{c}\text { Ele- } \\
\text { went. }\end{array}$ & Melting & Specific Heat. & Atomic Weight. \\
\hline 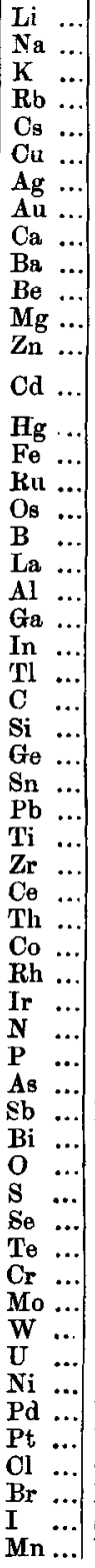 & 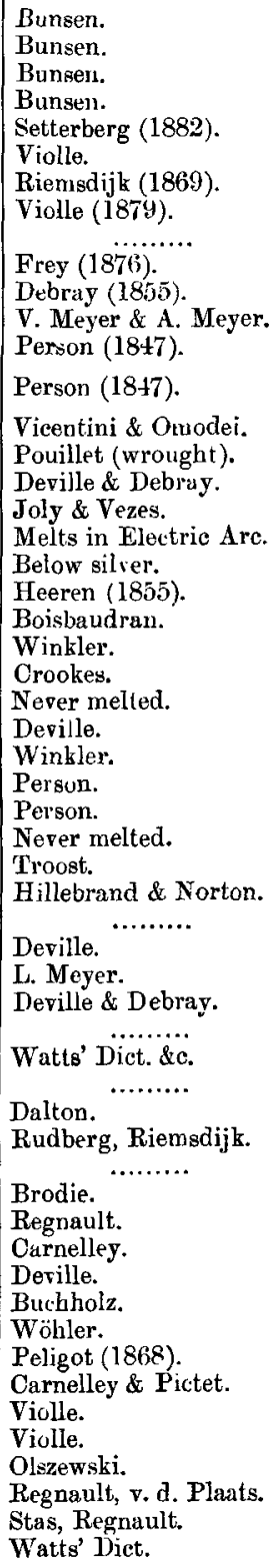 & 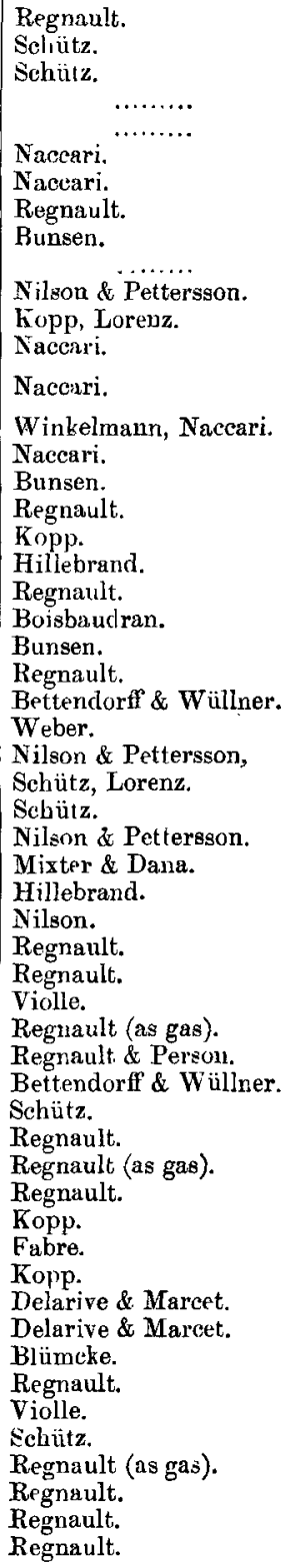 & $\begin{array}{l}\text { Stas. } \\
\text { Stas. } \\
\text { Stas. } \\
\text { Gorieffroy. } \\
\text { Bunsell. } \\
\text { Richards. } \\
\text { Stas. } \\
\text { Krïss. } \\
\text { Erdmann \& Marchand. } \\
\text { Dumas. } \\
\text { Nilson \& Pettersson. } \\
\text { Burton \& Vorce. } \\
\text { Gladstone \& Hibbert. } \\
\text { Morse \& Jones, } \\
\text { Lorimer \& Strith. } \\
\text { Erdmann \& Marchand. } \\
\text { Erdmann \& Marchand. } \\
\text { Joly. } \\
\text { Seubert. } \\
\text { Abraball. } \\
\text { Bettendorf, Brauner. } \\
\text { Mallet. } \\
\text { Boisbaudran. } \\
\text { Winkler. } \\
\text { Crookes. } \\
\text { Roscoe. } \\
\text { Thorpe \& Young. } \\
\text { Winkler. } \\
\text { v. d. Plaats. } \\
\text { Stas. } \\
\text { Thorpe. } \\
\text { Bailey. } \\
\text { Brauner, Norton. } \\
\text { Nilson \& Krüss. } \\
\text { Zimmermann. } \\
\text { Seubert \& Kobbé. } \\
\text { Seubert \& Joly. } \\
\text { Stas. } \\
\text { Scbröder. } \\
\text { Dumas. } \\
\text { Schröder. } \\
\text { Marignac. } \\
\text { Berzelius. } \\
\text { Stas. } \\
\text { Pettersson \& Eckmann. } \\
\text { Brauner. } \\
\text { Rawson, Meinecke. } \\
\text { L. Meyer. } \\
\text { Roscoe, Waddell. } \\
\text { Zimmermann. } \\
\text { Zimmermann. } \\
\text { Bailey \& Lamb. } \\
\text { Seubert. } \\
\text { Stas. } \\
\text { Stas. } \\
\text { Stas, Cooke. } \\
\text { Dewar \& Scott, Marignac. }\end{array}$ \\
\hline
\end{tabular}


The atomic heat affords another proof of Lothar Meyer's classification of sodium with the alkali metals, rather than that of Mendeléeff, who, followed by W. Preyer, places it in the copper group. Its chemical affinities to potassium are very close; thus E. Augé (Comptes Rendus, 1890, cx. p. 1139) obtained a sodium alum, by regulating both concentration and temperature.

To get comparable results, the specific heats must be observed at a constant temperature. With regard to meltingpoint, magnesium presents an irregularity in the zinc group, if the usual melting-point, $430^{\circ}$, is adopted ; but the number has been corrected by more recent observation, restoring complete harmony to the series. The order of melting-points of Sn and $\mathrm{Pb}$ in Group IV., and of $\mathrm{Sb}$ and $\mathrm{Bi}$ in Group V., both apparent anomalies, will be seen to favour, rather than contradict, the laws of atomic heat and fusion; for in both cases the atomic heats are reversed to correspund with the melting-points.

I have placed cobalt in IV. $b$, and nickel in VI.b, notwithstanding Zimmermann's values for their atomic weights ; and in doing so, as before, I have been guided entirely by the atomic heats, leading to Mendeléeff's original classification, which placed Co before $\mathrm{Ni}$ on purely chemical grounds, from the analogies of the former to $\mathrm{Rh}$ and $\mathrm{Ir}$, and of the latter to Pd and Pt (Ann. Supp. viii. p. 133 et seq.). Zimmermann (1886) finds $\mathrm{Ni}=58 \cdot 71, \mathrm{Co}=58 \cdot 89$.

The above tables appear to establish the following laws:-

1. In groups I. and II. (which I will call the metallic groups), as the atomic weight increases, both the meltingpoint and the atomic heat decrease.

2. In groups III. and IV. and all the $a$ groups (termed collectively intermediate groups) the atomic beat increases with the atomic weight, while the melting-point decreases; the former being characteristic of non-metals, the latter of metals.

3. In groups V., VI., and VII. (the non-metallic groups), as the atomic weight increases, so do both atomic heat and melting-point.

4. In the $b$ groups the melting-point increases with the atomic weight, whilst the atomic heat decreases; the former being a non-metallic, the latter a metallic characteristic.

The a may be called copper groups, and the $b$ iron groups.

It is to be noted that both groups IV. and V. become irregular in the same way when their last members are reached, these having more marked metallic characters. Thus hoth $\mathrm{Sn}$ and $\mathrm{Pb}$ in group IV., and $\mathrm{Sb}$ and $\mathrm{Bi}$ in $\mathrm{V}$., have 


\section{Mr. C. T. Blanshard on the Rôle of Atomic IJeat}

both melting-point and atomic heat in inverted order. The same order is found to hold in their latent heats of fusion. Thus Person fuund that tin requires $14 \cdot 25$ cals., whilst, according to Rudberg, lead requires only $5 \cdot 8$. There are no data for comparing antimony and bismuth. In the zinc group we find that the latent heat of fusion varies directly as the melting-point.

The irregularities in group III. $a$ as to melting-point cannot be explained in the above manner. The elements that follow $\mathrm{Al}$, viz. Ga, In, and $\mathrm{Tl}$, behave, as regards atomic heat and melting-point, like the non-metallic groups.

The inverse ratio between melting-point and atomic beat in the intermediate groups is well illustrated by carbon and boron. The former, which has never been melted, has the lowest atomic heat of all solid or liquid elements; whilst the latter, which is very infusible, has the next lowest.

If the above law's are true, they should enable meltingpoints not yet ascertained, as of thorium, molybdenum, \&c., to be predicted with tolerable accuracy. Thus, Th should melt at about $700^{\circ}$, Mo at about $2000^{\circ}$. Buchholz found this latter to be imperfectly fusible at a white heat. Again, the melting-points and specific heats of new elements should be capable of being predicted with much greater accuracy than has been possible hitherto. Thus Brauner's Bohemium (see 'Nature' for October 11, 1894) has bad the specific heat of 0)(03 predicted for it from Dulong and Petit's constant, but no melting-point. By referring to group VI., where it will occur after tellurium, $\mathrm{B} 0=213$, it is ensy to see that this element will have a melting-point of about $650^{\circ}$ and specific heat of aboui $\frac{6 \cdot 1}{213}=0.0286$.

\section{Volume-Heat.}

The following is a carefully calculated table of volumeheats, a further factor for comparing the elements, of value for their elassification, introduced by Dr. Wm. Preyer, Das genetische System der chemischen Elemente (Berlin, 18:3).

Volume-heat is the atomic heat $\div$ the atomic volume, and therefore $=\mathrm{CW} \div \frac{\mathrm{W}}{\mathrm{D}}=\mathrm{CD}$; where $\mathrm{C}$ is the specific heat, $\mathrm{W}$ the atomic weight, and $\mathrm{D}$ the specific gravity of the element.

The specific gravities are taken at $0^{\circ}$, and the specific heats at a constant temperature also, as near $15^{\circ}$ as possible. The natural groups are those of Lothar Meyer, as modified by 
W. Preyer. I have adopted Prof. Meyer's device of lettering the sub-groups, adding groups $b$ and $c$, as in the preceding article. The values are from Landolt and Börnstein, Phys.Chemische Tabellen, or more recent determinations.

\begin{tabular}{|c|c|c|c|c|}
\hline Group I. & C. & D. & CD. & Authorities. \\
\hline $\begin{array}{l}\text { Lithium ....... } \\
\text { Sodium ...... }\end{array}$ & $\begin{array}{c}0.94 \\
\cdot 283\end{array}$ & $\begin{array}{r}0.59 \\
.97\end{array}$ & $\begin{array}{r}0.555 \\
.274\end{array}$ & $\begin{array}{l}\text { Regnault, Bunsen. } \\
\text { Schütz, Gay-Lussac and Thénard. }\end{array}$ \\
\hline Potassium ... & & & & " \\
\hline $\begin{array}{l}\text { Group I. } a . \\
\text { Copper } \ldots \ldots . . \\
\text { Silver } \ldots \ldots \ldots . . \\
\text { Gold } \ldots \ldots \ldots\end{array}$ & $\begin{array}{r}0 \cdot 0924 \\
\cdot 0549 \\
\cdot 0316\end{array}$ & $\begin{array}{r}8 \cdot 94 \\
10 \cdot 53 \\
19 \cdot 33\end{array}$ & $\begin{array}{r}0.826 \\
.578 \\
.600\end{array}$ & $\begin{array}{l}\text { Naccari, various. } \\
\text { Naccari, Rose. } \\
\text { Violle, Rose. }\end{array}$ \\
\hline Group II. & & & & \\
\hline $\begin{array}{l}\text { Beryllium .... } \\
\text { Magnesium ... } \\
\text { Calcium ...... } \\
\text { Strontium ... }\end{array}$ & $\begin{array}{l}0 \cdot 424 \\
\cdot 245 \\
\cdot 1894 \\
\cdots \cdots\end{array}$ & $\begin{array}{l}1 \cdot 85 \\
1 \cdot 74 \\
1 \cdot 57 \\
2 \cdot 54 \\
3 \cdot 88\end{array}$ & $\begin{array}{r}0 \cdot 784 \\
.426 \\
.283 \\
\ldots \ldots . .\end{array}$ & $\begin{array}{l}\text { Nilson and Pettersson, H umpidge. } \\
\text { Kopp, Lorenz; Bunsen. } \\
\text { Bunsen, Matthiessen. } \\
\text { Quoted from F. W. Olarke. }\end{array}$ \\
\hline $\begin{array}{r}\text { Barium ...... } \\
\text { Group II. } a .\end{array}$ & ...... & & & $" \quad "$ \\
\hline $\begin{array}{l}\text { Zine } \ldots . . . . . . \\
\text { Cadmium .... } \\
\text { Mercury...... }\end{array}$ & $\begin{array}{l}0.0915 \\
.055 \\
.0331\end{array}$ & $\begin{array}{c}7 \cdot 10 \\
8 \cdot 55 \\
13 \cdot 596\end{array}$ & $\begin{array}{r}0 \cdot 650 \\
\cdot 470 \\
\cdot 448\end{array}$ & $\begin{array}{l}\text { Naccari, Rammelsberg. } \\
\text { Lorenz, Naccari ; Schröder. } \\
\text { Winkelmann, Regnault. }\end{array}$ \\
\hline Group II. $b$. & & & & \\
\hline $\begin{array}{l}\text { Tron } \ldots \ldots \ldots \\
\text { Ruthenium ... } \\
\text { Osmium ..... }\end{array}$ & $\begin{array}{r}0 \cdot 109 \\
.061 \\
\cdot 031\end{array}$ & $\begin{array}{r}7 \cdot 86 \\
12 \cdot 63 \\
22 \cdot 48\end{array}$ & $\begin{array}{r}0-857 \\
.769 \\
.696\end{array}$ & $\begin{array}{l}\text { Naceari, various. } \\
\text { Bunsen, Joly. } \\
\text { Regnault, Deville. }\end{array}$ \\
\hline Group III. & & & & \\
\hline Boron. & $0 \cdot 251$ & $2 \cdot 5$ ? & 0.627 & Mixter and Dana, Hampe. \\
\hline Alnminium... & 212 & 26 & .551 & $\begin{array}{l}\text { Regnault, Naceari; Jeville, Heeren, } \\
\text { Mallet. }\end{array}$ \\
\hline $\begin{array}{l}\text { Gallium ...... } \\
\text { Indium ..... } \\
\text { Thallium ... }\end{array}$ & $\begin{array}{l}\cdot 079 \\
\cdot 0569 \\
\cdot 0335\end{array}$ & $\begin{array}{r}5 \cdot 95 \\
7 \cdot 42 \\
11 \cdot 85\end{array}$ & $\begin{array}{l}\cdot 470 \\
.422 \\
.397\end{array}$ & $\begin{array}{l}\text { Berthelot, Boisbaudran. } \\
\text { Bunsen, Winkler. } \\
\text { Regnault, de la Rive. }\end{array}$ \\
\hline Group III. $a$. & & & & \\
\hline $\begin{array}{l}\text { Scandium ... } \\
\text { Yttrium ...... } \\
\text { Lanthanum .. }\end{array}$ & 0.0148 & $6 \cdot 1$ & $0 \cdot 273$ & Hillebrand and Norton. \\
\hline Group IV. & & & & \\
\hline $\begin{array}{l}\text { Carbon ....... } \\
\quad \text { (diamond). }\end{array}$ & $0 \cdot 204$ & $3 \cdot 158$ & 0.644 & $\begin{array}{l}\text { Bettendorff and Wüllner, v. Baum- } \\
\text { hauer. }\end{array}$ \\
\hline Silicon (cryst.) & $\cdot 177$ & $2 \cdot 39$ & 411 & Regnault, Winkler. \\
\hline $\begin{array}{l}\text { Germanium.. } \\
\text { Tin ........... }\end{array}$ & $\begin{array}{l}.073 \\
.054\end{array}$ & $\begin{array}{l}5 \cdot 469 \\
7 \cdot 29\end{array}$ & $\begin{array}{l}\cdot 399 \\
\cdot 393\end{array}$ & $\begin{array}{l}\text { Nilson and Pettersson, Winkler. } \\
\text { Schütz, Lorenz; Matthiessen. }\end{array}$ \\
\hline Lead ........... & .080 & $1 \mathrm{i} \cdot 352$ & 340 & Regnault, Lorenz; Reich. \\
\hline Group IV.a. & & & & \\
\hline $\begin{array}{l}\text { Titanium ... } \\
\text { Zirconium ... } \\
\text { Cerium ...... } \\
\text { Thorium...... }\end{array}$ & $\begin{array}{c}0 \cdot 1125 \\
.066 \\
.0148 \\
.0276\end{array}$ & $\begin{array}{r}4 \cdot 15 \\
6 \cdot 65 \\
11 \cdot 0\end{array}$ & $\begin{array}{r}0 \cdot 274 \\
\cdot 298 \\
.303\end{array}$ & $\begin{array}{l}\text { Nilson and Pettersson. } \\
\text { Mixter and Dana, Troost. } \\
\text { Hillebrand and Norton. } \\
\text { Nilson. }\end{array}$ \\
\hline
\end{tabular}

Phil. Mag. S. 5. Vol. 39. No. 236. Jan. 1895. 


\section{Atomic Heat in the Periodic Series of the Elements.}

Group IV. $b$.

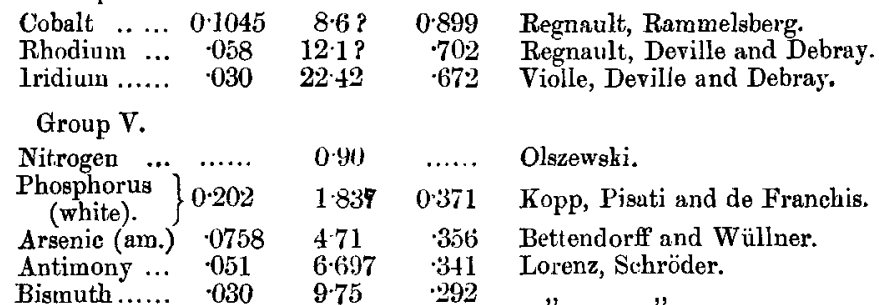

Table (continued).

Crystalline Arsenic has the values $\mathrm{C}=\cdot 083, \mathrm{D}=5 \cdot 73, \mathrm{CD}=0 \cdot 475$ (Eettendorff and Wüllner).

Group V.a. Vanadium, Niobium, and Tantalum have not had their speoific heats determined. Group VI.

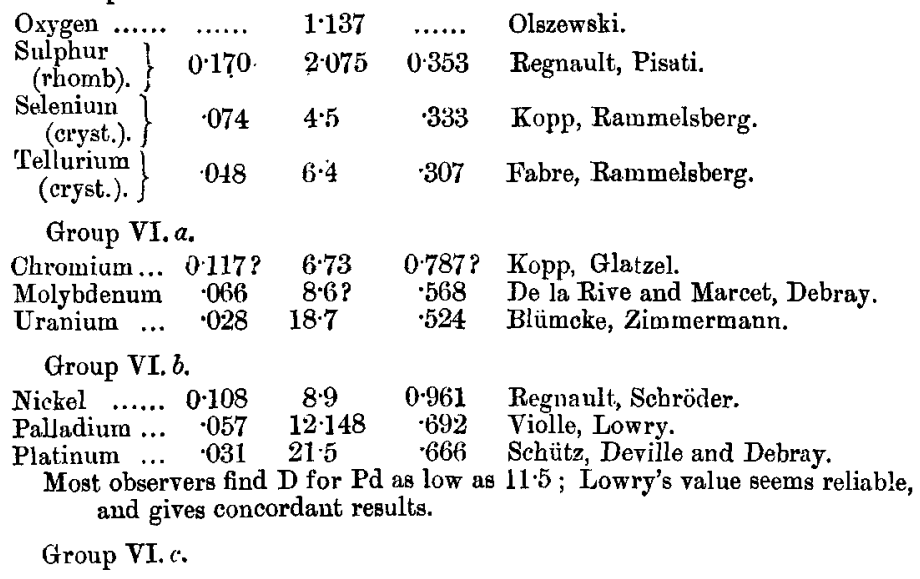

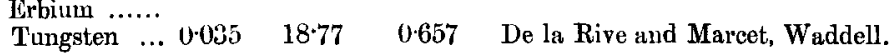

Group VII.

Fluorine......

Chlorine............ $\quad 1 * 46 \quad \ldots \ldots \quad$ Knietseh.

Bromine...... $0.084 \quad 3.187 \quad 0.268$ Regnault ; Pierre, Quincke,

Iodine $\quad \ldots . . \quad 054 \quad 4.95 \quad .267 \quad \begin{gathered}\text { v. d. Plats. } \\ \text { Regnault, Gay-Lussac. }\end{gathered}$

Chlorine is neglected, as are Oxygen and Nitrogen, because we bave only their specific heats as gases.

Group VII. $a$.

Manganeze... $0 \cdot 1217 \quad 7 \cdot 39 \quad 0.899 \quad$ Regnault, Glatzel.

It will be noted from the above that in group $I$. the atomic haats are nearly $\mathrm{Li}=4 a, \mathrm{Na}=2 a, \mathrm{~K}=a$, where $a$ is $0 \cdot 144$.

In group II., similarly, the ratio is $\mathrm{Be}=5 a, \mathrm{Mg}=3 a$, $\mathrm{Ca}=2 a$. 
In group VII. the volume-heats are constant.

Several elements, of known atomic weight, offer no data for both $\mathrm{C}$ and $\mathrm{D}$, and are altogether omitted.

The above tables make clear the following laws:-

1. In each natural group of elements volume-heat varies inversely as atomic volume. (Group IV. $a$ is an exception as far as available data go.)

2. The variations of volume-heat become less and less as valency for oxygen rises, until the seventh group is reached, when it becomes constant.

3. As atomic heat increases in some groups and decreases in others, with increase of atomic weight, whilst atomic volume regularly increases, it is evident that the increase in atomic volume proceeds at a higher ratio than the variation in atomic heat.

4. Atomic weight being a constant increment, it follows from the preceding law that in any natural group specific gravity varies more than specific heat.

VII. On a Suggestion by Professor J. J. Thomson in Connexion with the Luminescence of Glass due to KathodeRays. By JoHN Burke, B.A., Lecturer in Physics, Mason College, Birmingham**

T AST August, at Oxford, I communicated a paper to the L British Association on a strange luminous phenomenon which had been observed by Beccaria more than a hundred years ago. It was there pointed out that although the conclusions arrived at by the Italian physicist, if true, were likely to lead to results of an extremely interesting character, in connexion with Mr. Crookes' important researches on the luminescence of glass, \&c., in vacuum-tubes, and although the mysterious nature of the phenomenon was likely to attract much attention, yet the subject was allowed to retain its obscurity. Beccaria ('Artificial Electricity,' § 766) observed that when vacuum-bulbs were broken in the dark a light, consisting of a faint glow, was produced in the place where the bulb lay. He attributed an electrical origin to the phenomenon, owing to the manner in which certain substances were supposed to behave in yielding the glow. He mentioned, moreover, that the mere breaking of glass did not give rise to the phenomenon, but that the presence of air was essential to its production, and that when air was allowed to rush suddenly into a vacuum by the bursting of a bladder at the mouth of a

* Communicated by the Physical Society: read November 9, 1894. 